УДК 336.76

DOI: $10.25140 / 2411-5215-2020-3(23)-101-109$

Юлія Коваленко

\title{
ВПЛИВ КРЕДИТНО-ІНВЕСТИЦЙННОГО МЕХАНІЗМУ ФІНАНСУВАННЯ ЕКОНОМІЧНИХ ПРОЦЕСІВ НА РОЗВИТОК МАЛОГО ТА СЕРЕДНЬОГО БІЗНЕСУ
}

\author{
Юлия Коваленко
}

\section{ВЛИЯНИЕ КРЕДИТНО-ИНВЕСТИЦИОННОГО МЕХАНИЗМА ФИНАНСИРОВАНИЯ ЭКОНОМИЧЕСКИХ ПРОЦЕССОВ НА РАЗВИТИЕ МАЛОГО И СРЕДНЕГО БИЗНЕСА}

\author{
Yuliia Kovalenko \\ THE INFLUENCE OF THE CREDIT-INVESTMENT MECHANISM \\ OF FINANCING OF ECONOMIC PROCESSES ON THE DEVELOPMENT \\ OF SMALL AND MEDIUM BUSINESS
}

\begin{abstract}
У статті визначено різні теоретичні підходи щодо впливу кредитно-інвестиційного механізму фінансування економіки на розвиток малого та середнього бізнесу. Запропоновано ретроспективну концептуалізацію впливу кредитноінвестиційного механізму на розвиток економічних прочесів, зокрема сферу малого та середнього бізнесу. Окрему увагу приділено причинно-наслідковому зв'язку між темпами економічного розвитку й розвитком кредитно-інвестиційного механізму. Проаналізовано специфіку фінансування інвестиційної діяльності у сфері малого та середнього бізнесу в Украйні. Доведено, щзо банківська система та потенціал розвитку ринку цінних паперів в Украӥні не дають змоги розвивати потенціал малого та середнього бізнесу. Аргументовано, що недостатній розвиток кредитно-інвестиційного механізму фінансування економічних прочесів пояснюється незрілим інституиійним середовищем.
\end{abstract}

Ключові слова: кредитно-інвестиційний механізм; малий і середній бізнес; економічні процеси; інвестиції; кредити.

Рис.: 1. Бібл.: 20.

В статье определены различные теоретические подходы касательно влияния кредитно-инвестиционного механизма финансирования экономики на развитие малого и среднего бизнеса. Предложена ретроспективная концептуализация влияния кредитно-инвестиционного механизма на развитие экономических процессов, в частности сферу малого и среднего бизнеса. Отдельное внимание уделено причинно-следственной связи между темпами экономического развития и развитием кредитно-инвестиционного механизма. Проанализирована специфика финансирования инвестиционной деятельности в сфере малого и среднего бизнеса в Украине. Доказано, что банковская система и потенциал развития рынка ценных бумаг в Украине не дают возможности развивать потенциал малого и среднего бизнеса. Аргументированно, что недостаточное развитие кредитно-инвестиционного механизма финансирования экономических процессов объясняется незрелой институциональной средой.

Ключевые слова: кредитно-инвестиционный механизм; малый и средний бизнес; экономические процессы; инвестиции; кредиты.

Рис.: 1. Библ.: 20.

The article identifies various theoretical approaches to the impact of the credit and investment mechanism of financing the economy on the development of small and medium-sized businesses. A retrospective conceptualization of the impact of the credit and investment mechanism on the development of economic processes, in particular the sphere of small and medium business, is proposed. Particular attention is paid to the causal link between the pace of economic development and the development of the credit and investment mechanism. The specifics of financing investment activities in the field of small and medium business in Ukraine are analyzed. It is proved that the banking system and the potential development of the securities market in Ukraine do not allow to develop the potential of small and medium business. It is argued that the insufficient development of the credit and investment mechanism for financing economic processes is explained by the immature institutional environment.

Key words: credit and investment mechanism; small and medium businesses; economic processes; investments; loans.

Fig.: 1. References: 20

JEL Classification: G20

Постановка проблеми. 3 моменту набуття Україною незалежності та початку ринкових перетворень для всіх суб'єктів господарювання, зокрема малого та середнього бізнесу, постала необхідність пошуку інвестиційних вкладень за рахунок різних джерел. Подальший розвиток економічних процесів $є$ неможливим без активізації інвестиційних процесів та кредитних механізмів через активну і зважену інвестиційну політику. У сучасних умовах брак фінансових ресурсів як джерела інвестиційної діяльності підприє-

(c) Коваленко Ю. М., 2020 
мців стримує процеси подальшого формування та розвитку ринкової економіки в Україні. Результативність цієї діяльності залежить від заходів у напрямі вдосконалення кредитно-інвестиційного механізму фінансування економіки з тим, щоб забезпечити умови для подальшого розвитку малого та середнього бізнесу.

Аналіз останніх досліджень i публікацій. Проблеми впливу кредитноінвестиційного механізму на економічні зростання та розвиток стали об'єктом аналізу ще у XIX ст., причому цей вплив досліджувався в розрізі інших суміжних питань, зокрема оптимальної алокації фінансових ресурсів в економіці (В. Бейджхот), формуванні фінансових капіталів та ролі великих монополій (К. Маркс, Р. Гільфердінг). Найближче до цієї проблеми підійшов Й. Шумпетер, який дав оцінку ролі банківських установ у фінансуванні економічних суб'єктів. В Україні сучасну специфіку економічної діяльності та чинники розвитку економіки, зокрема сфери малого та середнього бізнесу, а також джерела ії фінансування, вивчають вітчизняні науковці, такі як 3. Варналій, Н. Версаль, О. Вовчак, О. Антонюк, І. Лютий, Р. Пікус, Н. Приказюк, Я. Чайковський та інші.

Виділення недосліджених частин загальної проблеми. У більшості досліджень кредитно-інвестиційного механізму фінансування економічних процесів акцентується на позитивних та негативних рисах різних його моделей, проте в них часто не беруться до уваги характеристики окремих видів економічної діяльності з їхніми суб'єктами, що не дозволяє оцінити відносну ефективність альтернативної моделі на різних етапах економічного розвитку країни. Структура факторів виробництва, що видозмінюється з часом, визначатиме потенціал їхнього розвитку та оптимальну структуру. Підприємства 3 різних видів економічної діяльності, зокрема малого та середнього бізнесу, мають властиві їм ризики та обсяги. Можна вважати, що попит на кредитні та інвестиційні ресурси залежить від структури капіталу такого суб'єкта, а також специфіки його діяльності. При цьому потрібно зважати на вплив кредитно-інвестиційного механізму фінансування економічних процесів на розвиток малого та середнього бізнесу загалом.

Головною метою цієї роботи $є$ ретроспективна концептуалізація впливу кредитноінвестиційного механізму фінансування економіки на розвиток малого та середнього бізнесу, а також визначення його специфіки в Україні на сучасному етапі.

Виклад основного матеріалу. Стійкий інтерес до проблеми впливу кредитноінвестиційного механізму фінансування економіки на розвиток малого та середнього бізнесу (далі - МСБ) спостерігається $з$ початку 60-х рр. ХХ ст. Першим дослідником цієї проблеми став Р. Голдсміт [13], який визначив зв'язок між фінансовим та економічним розвитком деяких країн і ввів коефіцієнт фінансової взаємозалежності як співвідношення обсягу фінансових ресурсів в економіці до ВВП (національного доходу). На основі вивчення даних 35 банківських систем країн світу за 1860-1963 рр. було зроблено висновок про те, що на довгострокову перспективу паралельно відбувається фінансовий та економічний розвиток МСБ, а у більшості випадків (за деякими винятками) вищі темпи економічного зростання супроводжуються одночасно і більшими темпами фінансового розвитку. Інший дослідник, Р. МакКіннон [17], проілюстрував зв'язок між кредитно-інвестиційним механізмом та економічним розвитком МСБ у таких країнах, як Бразилія, Німеччина, Індонезія, Корея, Тайвань та Чилі в післявоєнний період. Висновки є цілком однозначні: хоча кредитно-інвестиційний механізм розвивається через потреби суб'єктів МСБ, добре функціонуючий такий механізм за певних умов і певного історичного періоду помітно прискорює їхній розвиток.

Багато емпіричних досліджень продемонстрували існування стійких зв'язків між рівнем розвитку кредитно-інвестиційного механізму фінансування економічних процесів і темпами розвитку МСБ. Так, Р. Раджан і Л. Зінгалес [18] стверджують, що розвинутий кредитно-інвестиційний механізм сприяє насамперед розвитку тих суб'єктів МСБ, які 
ФІНАНСОВІ РЕСУРСИ: ПРОБЛЕМИ ФОРМУВАННЯ ТА ВИКОРИСТАННЯ

суттєво залежать від зовнішнього фінансування. Регресійний аналіз дослідив їм проаналізувати велику кількість видів економічної діяльності в різних країнах та впевнитися в тому, що більш залежні від зовнішнього кредитно-інвестиційного фінансування види діяльності розвивались швидше там, де в країні було сформовано розвинутий фінансовий сектор. Результати цієї роботи дозволили зробити й інший висновок: високий рівень розвитку кредитно-інвестиційного механізму фінансування економіки істотно сприятиме розвитку нових форм МСБ, наукомістких видів економічної діяльності (зокрема у сфері фармацевтики та комп'ютерних технологій), які потребують фінансування на довгий інвестиційний горизонт.

Підтвердженням «теорії первинності фінансового розвитку» (financial led growth) стали роботи П. Руссо і Р. Сілла (1999) [19; 20], де було досліджено 17 країн із властивою їм історією, де початком є XVIII ст. Аналіз даних щодо економічного розвитку таких країн, як Голландія за 1600-1794 pр., Англія за 1700-1850 pp., США за 17901850 pр. і Японія у 1880-1913 рр. дав змогу дійти висновку, що саме поява ефективного кредитно-інвестиційного механізму з його фінансовими інститутами, інструментами й відповідними ринками відіграла визначальну роль у розвитку цих економік, зокрема $\mathrm{i}$ щодо активізації діяльності у сфері МСБ.

Окремим дослідникам вдалось проілюструвати причинно-наслідковий зв'язок між темпами економічного розвитку та розвитком кредитно-інвестиційного механізму фінансування економічних процесів. Так, Р. Кінг і Р. Левайн $[14 ; 15]$ продовжили дослідження вищезгаданого Р. Голдсміта і розглянули вже показники розвитку 57 країн світу у 1960-1989 рр. із доповненням його низкою інших індикаторів. Вони прагнули відповісти на таке складне питання: чи передбачатиме підвищення ефективності кредитно-інвестиційного механізму зростання темпів економічного зростання загалом, накопичення капіталу та зростання продуктивності праці, зокрема у сфері МСБ? Р. Кінг і Р. Левайн запропонували показники, за якими можна давати оцінку кредитноінвестиційного потенціалу і які використовуються донині, зокрема це показники: «1) фінансової глибини (DEPTH) - відношення ліквідних пасивів фінансових посередників (готівка та депозити кредитних інститутів (M2) до ВВП; 2) частка комерційних банків у кредитах (BANK) - відношення кредитів комерційних банків до загальної суми кредитів плюс активів центрального банку; 3) кредити приватному бізнесу (PRIVAT) - відношення кредитів приватному бізнесу до загальної суми кредитів (за винятком міжбанківських); 4) відношення кредитів приватним підприємствам до ВВП (PTIVY)» [6, с. 127].

Як показники зростання Р. Кінгом і Р. Левайном було обрано темпи зростання: 1) реального (у постійних цінах) ВВП на душу населення; 2) основного капіталу на душу населення; 3) продуктивності праці. Щодо питання причинно-наслідкового зв'язку між кредитно-інвестиційним механізмом і економічним розвитком, то вони шукали відповідь на таке питання: як рівень фінансової глибини у базисному 1960 р. дозволить прогнозувати на наступні 30 років темпи економічного зростання, а також накопичення капіталу і продуктивність праці. Вибудовані Р. Кінгом і Р. Левайном рівняння регресії показали високу прогнозованість, власне, показника самої фінансової глибини. Недоліком роботи вважається використання даних лише про кредитні ресурси, тобто банки, що не дало змоги дослідити вплив на економіку інших складових кредитно-інвестиційного механізму. Крім цього, як зазначає Б. Рубцов, «не зрозуміло, у чому полягає механізм передавання імпульсів із фінансового сектору до реального i чи прискорює ефективніша фінансова система економічне зростання переважно за рахунок вищого рівня інвестицій або за рахунок спрямування інвестицій у найпродуктивніші галузі та підприємства» [7], особливо в досліджуваній нами сфері МСБ. 
Інші вчені, такі як Т. Бек, Р. Левайн і Н. Лоайза [10; 16], досліджували чинники впливу на кредитно-інвестиційний механізм, зокрема вплив розвитку банків на динаміку норми заощаджень, інвестицій і продуктивності праці на базі аналізу показників економічного розвитку 63 країн за період 1960-1995 рр. При цьому проведене дослідження не підтвердило існування стійкого зв'язку між рівнем розвитку кредитних установ та нормою заощаджень та інвестиціями, натомість було виявлено взаємозв'язок між розвитком кредитно-інвестиційного потенціалу, зростанням реального ВВП на душу населення, а також продуктивністю праці. Пізніше Т. Бек, А. Деміргуч-Кунт і Р. Левайн [9] створили базу даних кредитно-інвестиційних механізмів економік 150 країн за період 1960-1995 рр., що дозволило виявити, що самі фінансові установи як донори та реципієнти фінансових ресурсів $\epsilon$ більш розвинутими й ефективнішими в багатших країнах, причому зі зростанням багатства конкретних країн ринки акцій стають активнішими та ефективнішими порівняно з ринками банківського кредитування. Особливо це стосується суб'єктів МСБ, які шукають різні можливості для фінансування свого розвитку за рахунок внутрішнього ринку капіталу. У свою чергу, А. Деміргуч-Кунт і В. Максимович [12] на основі аналітичних даних різних компаній довели, що підприємства МСБ зростатимуть швидшими темпами там, де можна легше одержати зовнішнє фінансування.

Ще одна група дослідників, зокрема Ц. Калдерон і Л. Лью [11] за використання показників 109 країн світу за період 1960-1994 рр. показала наявність прямого зв'язку між розвитком кредитно-інвестиційного механізму фінансування економічних процесів та розвитком МСБ. Було виявлено, що вплив першого на другий $є$ важливішим за вплив другого на перший. Також було припущено, що недостатній розвиток МСБ буде стримувати економічний розвиток, особливо у країнах, що розвиваються.

Р. Раджан і Л. Зінгалез [18] доводять, що у країнах із розвинутим кредитноінвестиційним механізмом суб'єкти МСБ, що потребують значних залучених ресурсів, зростають швидше за інших. I навпаки, у країнах, які мають нерозвинутий кредитноінвестиційний механізм, вони розвиваються повільніше. Робота цих авторів продемонструвала високий рівень розвитку кредитно-інвестиційного потенціалу у 1913 р. (навіть порівняно з 1999 р.). «Середній розмір депозитів відносно ВВП у 1913 р. наближений до показника 1980 р. Винятком є Японія, де депозити становили 19 \% у 1913 р., а у 1999 - $111 \%$. Випуск акцій мав більшого значення у 1913 р. порівняно з наступними роками. Тільки наприкінці 1990-х р. величина ринків акцій щодо ВВП перевищила рівень 1913 р.» [6, с. 130]. Комплексна оцінка розвитку кредитно-інвестиційного потенціалу групи розвинутих країн загалом дозволила зробити висновок, що у 1913 р. цей рівень був той самий, що і в 1999 р., а у 1989 р. був нижче базового показника.

Сьогодні, як і понад 100 років тому, існують суттєві відмінності між різними групами країн. За більшістю даних МСБ країн континентальної Свропи був більш розвинутим порівняно з США. Усі країни у період 1913-1980 pp. погіршили показники розвитку кредитно-інвестиційного потенціалу. Перша світова війна не чинила радикального впливу на кредитно-інвестиційний потенціал країн. У 1929 р. переважна більшість індикаторів фінансового розвитку МСБ були наближені до довоєнного періоду. $Є$ цікавим, що Велика депресія не показала негайного ефекту на рівень розвитку кредитноінвестиційного механізму, а зниження його показників відбулось вже у 1940-і pp. У 1950 p., через 5 років після закінчення Другої світової війни, усі показники були суттєво нижчими, ніж напередодні цієї війни. «Депозити - 32 \% ВВП, капіталізація - 29 \%, емісія акцій $-6 \%$ від валових інвестицій» [6, с. 130]. Зниження не обмежувалось лише тими державами, що зазнали поразки у війні. У цей список увійшли також Швеція, Аргентина та Бразилія. 
ФІНАНСОВІ РЕСУРСИ: ПРОБЛЕМИ ФОРМУВАННЯ ТА ВИКОРИСТАННЯ

Лише наприкінці XX ст. став можливим подальший розвиток кредитноінвестиційного механізму фінансування економіки для МСБ. Так, на у 1970-1980 pp. у Японії та країнах Європи був скасований контроль над рухом фінансового капіталу, а США почали впроваджувати лібералізацію своєї фінансової системи. Позитивно вплинуло на розвиток кредитно-інвестиційного механізму фінансування економічних процесів та МСБ створення Свропейського Союзу, що відкривало місцевий ринок для конкуренції та давало можливості створювати нові ринки.

У країнах, що розвиваються, спостерігається прямий зв'язок між розвитком кредитно-інвестиційного механізму фінансування економічних процесів та економічним розвитком МСБ, проте в цих процесах провідну роль відіграють банки через низький розвиток фондового ринку. За сучасних умов із підвищенням рівня розвитку економіки збільшується фінансова глибина та диверсифікованість джерел фінансування МСБ, натомість зменшується частка банків в активах фінансової системи загалом. За нашими підрахунками, «у розвинених країнах частка банківського сектору знаходиться у межах 30-80 \% активів (зона середніх значень - 60-70 \%). У країнах, що розвиваються, частка банківського сектору є вищою (50-90 \%) (зона середніх значень - 75-85 \%)» [6, с. 137].

Щодо розвитку банківської системи в Україні як визначальної для формування кредитно-інвестиційних процесів фінансування економічних процесів i розвитку МСБ, то на перших етапах розвитку економіки відбулось суттєве зниження попиту на депозити банків i, як наслідок, відтік грошових ресурсів із фінансового сектору, що тільки-тільки набував розвитку. Основною причиною став великий обсяг заощаджень населення у дореформений період, що був зумовлений дефіцитом товарної маси, а після запровадження лібералізації цін і появи на ринку імпорту населення країни інтенсивно знімало кошти з депозитних рахунків, а решта коштів зазнала знецінення через гіперінфляцію.

3 того часу зростання капітальних інвестицій в Україні забезпечене ендогенною пропозицією грошей (рис. 1). Зокрема питома вага банківських та інших кредитів з 2000 по 2008 рр. зросла 31,7 до 17,4\%, тобто практично у 10 разів, а на початок 2020 р. становила лише $10,8 \%$. Швидке нарощування операцій банків забезпечується активізацією їхньої посередницької діяльності, що проявилось у зростанні попиту передусім сфери МСБ на кредитні ресурси. Проте кредитний бум пов'язують здебільшого з наданням кредитів без відповідного забезпечення, а також валютизацією і зниженням вимог до позичальників сфери МСБ, що в підсумку послабило ризикменеджмент і призвело до зростання фінансових ризиків.

«У посткризовий період відновились інвестиції в реальний сектор, однак основне джерело інвестиційних ресурсів - це власні кошти підприємств і організацій, причому з тенденцією до зменшення їхньої питомої ваги за 2002-2012 pp. 3 65,8 до 59,7\%. Частка кредитів банків та інших позик скоротилась за 2008-2019 pp. із 17,3 до 10,8 \%» [4, с. 104]. Структура кредитів МСБ показує, що тут переважало кредитування торгівлі та операцій із нерухомим майном, оренди, інжинірингу та надання послуг підприємцям, що становило $52,1 \%$. 
ФІНАНСОВІ РЕСУРСИ: ПРОБЛЕМИ ФОРМУВАННЯ ТА ВИКОРИСТАННЯ

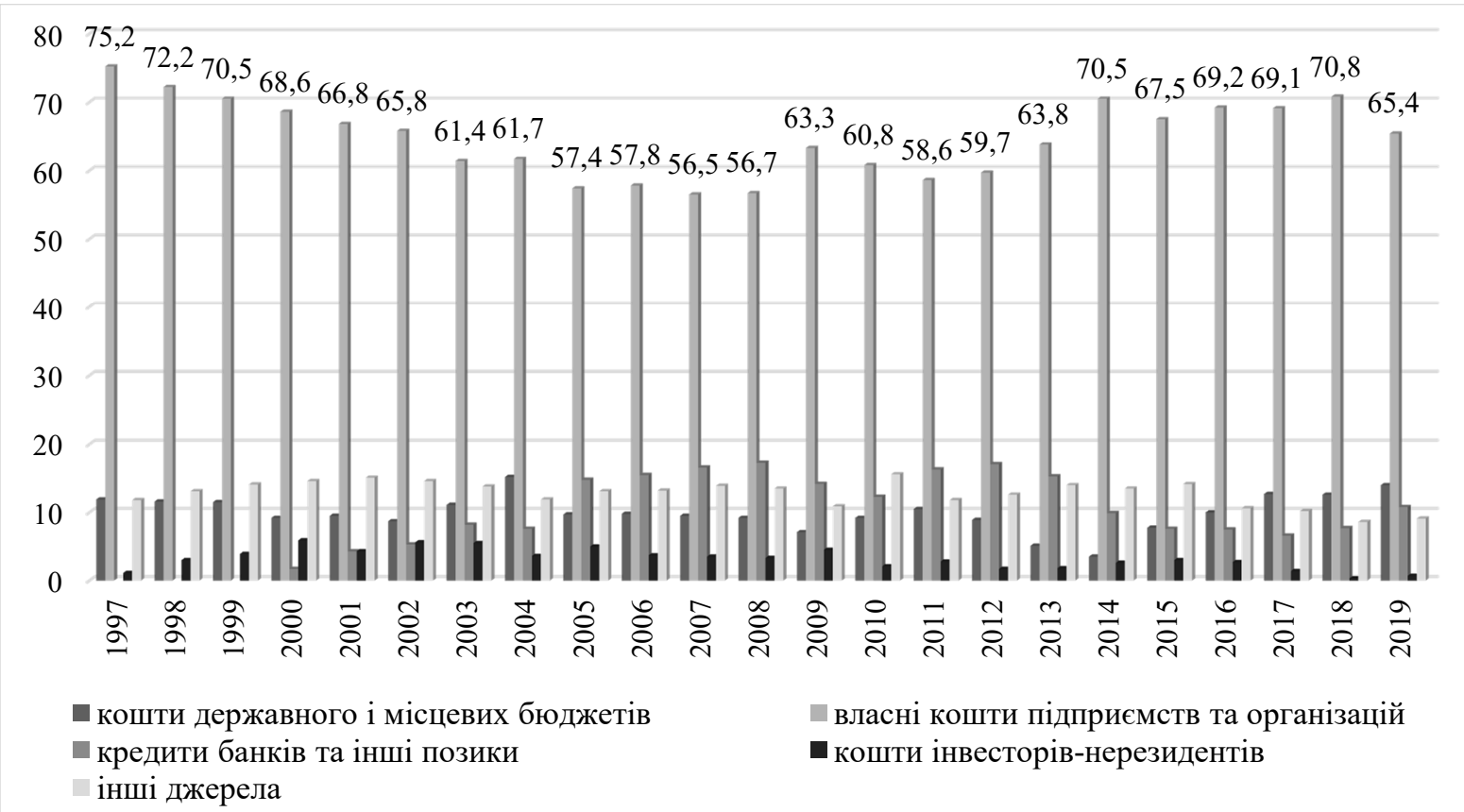

Рис. 1. Джерела фінансування у структурі капітальних інвестицій в Україні y 1997-2019 pp., \%

Джерело: розраховано та побудовано за даними [1].

Тенденції розвитку національної банківської системи засвідчують, що вона поки що не в змозі відповідати потребам економічного розвитку МСБ. Тут варто згадати і про фінансово-відсотковий важіль, коли за різниці відсоткових ставок в Україні і країнах ЄС інституційні одиниці і фінансового, і реального сектору позичають фінансові ресурси за кордоном, збільшуючи ти самим державний зовнішній борг. 3 його зростанням виникають проблеми з девальвацією: якщо вона виникає, то гривневі еквіваленти такого боргу одразу ж зростають та стають важким тягарем для деградованого МСБ економіки. Без сумніву, не можна розвивати конкурентоспроможний МСБ без кредитування, але запозичені за кордоном України ресурси вкладаються не в нього, а переважно в сировинні види економічної діяльності, які визначають експортний потенціал держави, а також у реалізацію міжбанківських операцій, валютних спекуляцій, операцій із нерухомістю тощо.

Високі відсоткові ставки за логікою органів-регуляторів в Україні мали б протидіяти інфляційним процесам і залучати прямі іноземні інвестиції. Однак в умовах дисбалансу рентабельності секторів економіки високі відсотки дозволяють розвиватися лише тим видам економічної діяльності, рентабельність яких перевищує ці відсотки. Це зокрема стосується фінансів та страхування, енергетики, видобувних виробництв, металургії, нафтохімії тощо. Решта продуктивних сфер за таких відсотків штучно стає неефективною. Це призводить до: 1) неефективної монополістичної структури економіки з високими витратами; 2) низького рівня рентабельності та норми інвестицій; 3) низького розміру продуктової маси на внутрішніх ринках; 4) високої інфляції. Високі відсотки та низький рівень рентабельності провокують подальші деградаційні процеси всієї економічної системи країни, не говорячи вже про МСБ. У країні морально старий і зношений основний капітал, знищено практично повністю парк верстатів, а також механізми реального відновлення основного капіталу. Як влучно пише О. Сухарєв, «якщо відсоток відображує вартість основного капіталу, то чому зношені речі так дорого коштують?... Високий відсоток підвищує схильність до спекулятивної гри, а не виробничої діяльності, не дозволяючи реалізувати більшості нових ідей, винаходів, НДДКР тощо» [8, с. 327-328]. 
ФІНАНСОВІ РЕСУРСИ: ПРОБЛЕМИ ФОРМУВАННЯ ТА ВИКОРИСТАННЯ

I потенціал фондового ринку поки що не забезпечує повною мірою економічний розвиток МСБ в Україні. На нашу думку, причинами $\epsilon$ неефективне корпоративне управління, недостатня кількість фінансових інструментів, що прийнятні для інвестування i, врешті-решт, низька фінансова культура, ментальні норми тощо.

За нашими дослідженнями, загалом «роль фінансової системи в розподілі матеріальних і фінансових ресурсів важко переоцінити» [19, с. 75]. Недостатній розвиток кредитно-інвестиційного механізму фінансування економічних процесів, зокрема і МСБ, в Україні пояснюється незрілим інституційним середовищем, де недостатньо чітко сформульовано права власності, існує асиметрія інформації і великі трансакційні витрати, невиконання контрактних зобов'язань, непрозорість діяльності більшості емітентів, участь банків у схемних угодах тощо. «Його ігнорування істотно обмежує можливості фінансової науки у формуванні адекватних уявлень про економічну реальність...» [2, c. 42]. Проте 3 подальшою еволюцією та системним перетворенням ключових інституцій МСБ набуде більш цивілізованого вигляду, що доводить, власне, світова практика.

Висновки і пропозиції. Кредитно-інвестиційний механізм фінансування економічних процесів в Україні не чинить впливу на економічний розвиток МСБ, оскільки він забезпечується насамперед власними коштами. Ситуація, де суб'єкти господарювання МСБ використовують для його фінансування власні кошти призводить до того, що фінансові посередники, насамперед банки, не беруть на себе інвестиційні ризики. Зі зменшенням боргового фінансування ризики підприємців підвищуються, що загалом призводить до зниження економічних показників.

Варто розвивати тезу про більш швидкий розвиток кредитно-інвестиційного механізму фінансування економічних процесів з сильним ринком капіталу і МСБ з підкресленням зворотного зв'язку між цими параметрами. Можна зауважити, що розвинуті ринки народжують більше багатство й розвиток підприємств різної форми. Можливо, правильним $€$ і зворотне твердження: багатим і розвинутим країнам світу відповідатиме більш розвинутий і адекватний кредитно-інвестиційний механізм фінансування функціонування МСБ через створення для цього необхідних умов, передусім економічних та економічних. Іншими словами, розвиток МСБ $\epsilon$ наслідком розвитку кредитноінвестиційного механізму фінансування економічних процесів.

\section{Список використаних джерел}

1. Державна служба статистики. URL http://www.ukrstat.gov.ua.

2. Детермінанти розвитку публічного управління та адміністрування в Україні : колективна монографія / за заг. ред. Н. С. Орлової. Київ : ВД «Освіта України», 2020. 262 с.

3. Дубина М. В. Механізм розвитку ринку фінансових послуг на основі формування інституту довіри: теорія, методологія, практика : монографія. Чернігів : ЧНТУ, 2018. 668 с.

4. Коваленко Ю., Коваль І., Близненко Є. Вплив моделі сектору фінансових корпорацій і ринку цінних паперів на інвестиційні процеси в Україні. Проблеми і перспективи економіки та управління. 2020. № 2 (22). С. 98-111.

5. Коваленко Ю. М. Фінансова система і фінансовий сектор: організаційно-інституційний підхід. Фінанси Украӥни. 2011. № 4. С. 75-87.

6. Регулятивний потенціал фінансового ринку в умовах глобальних викликів : монографія / за ред. д.е.н., проф. С. В. Онишко. Ірпінь : УДФСУ, 2016. 452 с.

7. Рубцов Б. Б. Эволюция институтов финансового рынка и развитие экономики / Финансовые институты и экономическое развитие. URL: www.mirkin.ru/_docs/Rub_evolfin.pdf.

8. Сухарев О. С. Возможности экономической науки и развитие экономики. Бюлетень Міжнародного Нобелівського економічного форуму. 2010. № 1 (3). Т. 1. С. 327-328.

9. Beck T., Demirgüç-Kunt A., Levine R. A New Database on Financial Development and Structure. World Bank Economic Review. 1999. № 14. Pp. 597-605. 
10. Beck T., Levine R., Loayza N. Finance and the Sources of Growth. Journal of Financial Economics. 2000. № 58. Pp. 261-300.

11. Calderon C., Liu L. The Direction of Causality between Financial Development and Economic Growth. Journal of Development Economics. 2003. № 72. Pp. 321-334.

12. Demirgüç-Kunt A., Maksimovic V. Stock Market Development and Firm Financing Choices. World Bank Economic Review. 1996. № 10. Pp. 341-370.

13. Goldsmith R. W. Financial Structure and Economic Development. New Haven: Yale University Press, 1969. 158 p.

14. King R., Levine R. Finance and Growth: Schumpeter Might Be Right. Quarterly Journal of Economics. 108 (August 1993). Pp. 717-738.

15. King R., Levine R. Finance, Entrepreneurship, and Growth: Theory and Evidence. Journal of Monetary Economics. 32 (December 1993). Pp. 513-542.

16. Levine R., Loayza N., Beck T. Financial Intermediation and Growth: Causality and Causes. Journal of Monetary Economics. 2000. № 46 (1). Pp. 31-77.

17. McKinnon R. Money and Capital in Economic Development. Washington, DC: Brookings Institution, 1973. $182 \mathrm{p}$.

18. Rajan R. G., Zingales L. Financial Dependence and Growth. American Economic Review. 1998. № 88. Pp. 559-586.

19. Rousseau P. L., Sylla R. Emerging Financial Markets and Early U.S. Growth. National Bureau of Economic Research Working Paper. 1999. № 7448. Pp. 658-669.

20. Rousseau P. L., Sylla R. Financial System, Economic Growth and Globalization. National Bureau of Economic Research Working Paper. 2001. № 8323. Pp. 865-934.

\section{References}

1. Derzhavna sluzhba statystyky Ukrainy [State Statistics Service of Ukraine]. http://www.ukrstat.gov.ua.

2. Orlova, N. S. (Ed.). (2020). Determinanty rozvytku publichnoho upravlinnia ta administruvannia $v$ Ukraini [Determinants of development of public administration and administration in Ukraine]. Osvita Ukrainy.

3. Dubyna, M. V. (2018). Mekhanizm rozvytku rynku finansovykh posluh na osnovi formuvannia instytutu doviry: teoriia, metodolohiia, praktyka [The mechanism of development of the financial services market based on the formation of the institute of trust: theory, methodology, practice]. ChNTU.

4. Kovalenko, Yu., Koval, I., Bliznenko, Ye. (2020). Vplyv modeli sektoru finansovykh korporatsii i rynku tsinnykh paperiv na investytsiini protsesy v Ukraini [Influence of the model of the financial corporations sector and the securities market on investment processes in Ukraine]. Problemy $i$ perspektyvi ekonomiky ta upravlinnia - Problems and prospects of economics and management, 2 (22), pp. $98-111$.

5. Kovalenko, Yu. M. (2011). Finansova systema i finansovyi sektor: organizatsiino-institutsiinyi pidkhid [Financial system and financial sector: organizational and institutional approach]. Finansy Ukrainy - Finance of Ukraine, 4, pp. 75-87.

6. Onyshko, S. V. (Ed.). (2016). Rehuliatyvnyi potentsial finansovoho rynku v umovakh hlobalnykh vyklykiv [Regulatorny potential of the financial market in terms of global challenges]. UDFSU.

7. Rubtsov, B. B. (n.d.). Evolyuciya institutov finansovogo rynka i razvitie ekonomiki [Evolution of financial market institutions and economic development]. Finansovye instituty $i$ ekonomicheskoe razvitie - Financial institutions and economic development. www.mirkin.ru/_docs/Rub_evolfin.pdf.

8. Suharev, O. S. (2010). Vozmozhnosti ekonomicheskoj nauki i razvitie ekonomiki [Possibilities of economic science and economic development]. Biuleten Mizhnarodnoho Nobelivskoho ekonomichnoho forumu - Bulletin of the International Nobel Economic Forum, 1(1(3)), pp. 327-328.

9. Beck, T., Demirgüç-Kunt, A., Levine, R. (1999). A New Database on Financial Development and Structure. World Bank Economic Review, 14, pp. 597-605.

10. Beck, T., Levine, R., Loayza, N. (2000). Finance and the Sources of Growth. Journal of Financial Economics, 58, pp. 261-300.

11. Calderon, C., Liu, L. (2003). The Direction of Causality between Financial Development and Economic Growth. Journal of Development Economics, 72, pp. 321-334. 
ФІНАНСОВІ РЕСУРСИ: ПРОБЛЕМИ ФОРМУВАННЯ ТА ВИКОРИСТАННЯ

12. Demirgüç-Kunt, A., Maksimovic, V. (1996). Stock Market Development and Firm Financing Choices. World Bank Economic Review, 10, pp. 341-370.

13. Goldsmith, R. W. (1969). Financial Structure and Economic Development. Yale University Press.

14. King, R., Levine, R. (1993). Finance and Growth: Schumpeter Might Be Right. Quarterly Journal of Economics, pp. 717-738.

15. King, R., Levine, R. (1993). Finance, Entrepreneurship, and Growth: Theory and Evidence. Journal of Monetary Economics, pp. 513-542.

16. Levine, R., Loayza, N., Beck, T. (2000). Financial Intermediation and Growth: Causality and Causes. Journal of Monetary Economics, 46 (1), pp. 31-77.

17. McKinnon, R. (1973). Money and Capital in Economic Development. DC: Brookings Institution.

18. Rajan, R. G., Zingales, L. (1998). Financial Dependence and Growth. American Economic Review, 88, pp. 559-586.

19. Rousseau, P. L., Sylla, R. (1999). Emerging Financial Markets and Early U.S. Growth. National Bureau of Economic Research Working Paper, 7448, pp. 658-669.

20. Rousseau, P. L., Sylla, R. (2001). Financial System, Economic Growth and Globalization. National Bureau of Economic Research Working Paper, 8323, pp. 865-934.

Коваленко Юлія Михайлівна - доктор економічних наук, професор, професор кафедри фінансових ринків, Університет державної фіскальної служби України (вул. Університетська, 31, м. Ірпінь, 08201, Україна).

Коваленко Юлия Михайловна - доктор экономических наук, профессор, профессор кафедры финансовых рынков, Университет государственной фискальной службы Украины (ул. Университетская, 31, г. Ирпень, 08201, Украина).

Kovalenko Yuliia - Doctor of Economics, Professor, Professor of Financial Markets Department, University of the State Fiscal Service of Ukraine (31 Universitetska Str., 08201 Irpin, Ukraine).

E-mail: kovalenko0202@ukr.net

ORCID: htpp://orcid.org./0000-0002-5678-3185

ResearcherID: H-4742-2018

Коваленко Ю. Вплив кредитно-інвестиційного механізму фінансування економічних процесів на розвиток малого та середнього бізнесу. Проблеми і перспективи економіки та управління. 2020. № 3(23). С. 101-109. 